\title{
Is There a Text in This Child? Childness and the Child-Authored Text
}

\section{Clémentine Beauvais ${ }^{1}$}

Published online: 5 February 2019

(c) The Author(s) 2018

\begin{abstract}
This article explores child-authored texts, both real and fictional, and the adult discourse surrounding or commenting on such texts. It focuses on the example of young Marcel's writing in Proust's In Search of Lost Time, and on the critical commentary on the juvenilia of child authors of the nineteenth and early twentieth century. I argue, using Peter Hollindale's concept of childness, that adult texts written about and around child-authored texts have a tendency to perform, themselves, the kind of childly characteristics that they hope to see in the children's texts. The childness of child-authored texts is an all-but-illusory characteristic if it is envisaged as an intrinsic or essential feature of the texts; however, the adult awareness of the existence of a child-authored text shapes and deforms adult discourse around it in ways that are attributable, at least in part, to the characteristics of childness expected of young writers in a given place and time. Thus, I conclude, the adult text ends up more childly than the child's; and, by conditioning the reader's approach to the child's text as childly, it is the adult's text, paradoxically, that contaminates it with childness.
\end{abstract}

Keywords Child-authored texts · Juvenilia $\cdot$ Childness $\cdot$ Proust $\cdot$ Child writers $\cdot$ Adult · Peter Hollindale

\footnotetext{
Clémentine Beauvais is a Senior Lecturer at the Department of Education, University of York (UK). Her research interests revolve around children's literature theory, the philosophy and cultural sociology of childhood, and translation theory. She is the author of many articles and book chapters on topics such as politically committed children's literature, child giftedness in literature and culture, and Simone de Beauvoir's philosophy of childhood. Her monograph The Mighty Child: Time and Power in Children's Literature (John Benjamins, 2015), presents an existentialist reading of contemporary children's literature. She also recently co-edited The Edinburgh Companion to Children's Literature (Edinburgh University Press, 2017) with Maria Nikolajeva.
}

Clémentine Beauvais

clementine.beauvais@york.ac.uk

1 York, UK 


\section{Introduction: Steeplechase}

Towards the end of Marcel Proust's Swann's Way (1913/2005, p. 216), the young narrator, in a sudden (and short-lived) outburst of creativity, writes a poetic description of the church steeples in the small village of Martinville, approached by carriage. In the next volume (Proust, 1919/2005), the teenager presents his writing to the snobbish M. de Norpois, who first elects to remain silent, but later explains to Marcel exactly why the piece is a tasteless "griffonnage d'enfant" ("child's scrawl"). It is quite normal, however, Norpois reassures Marcel, that at his age he should be unable to attempt literary sophistication with any degree of success.

"Les clochers de Martinville" (the steeples of Martinville) is among the most famous and studied extracts from In Search of Lost Time. It is not just the birth of young Marcel's literary vocation, but also the most significant glimpse we ever get, intradiegetically, of the narrator's writing. Editors generally signpost to readers that the text is in fact an insert, a self-quotation by Proust (e.g. Keller, 1980), who had previously published a similar piece about the steeples of Caen in Le Figaro (Pholien, 1964; Mousson, 1995). Proust, therefore, passes off a mature piece as juvenilia. Or rather, to be precise, Proust the author passes off his own mature work as the juvenilia of his fictional character, Marcel. This should not be surprising, of course; In Search of Lost Time being a novel, there is no reason for Proust the writer to have used his own ("real") juvenilia, awkwardly attributing it to his fictional character. And the reader, unless very naïve, knows that the passage was not written by a young Proust.

Yet the inclusion of the "steeples of Martinville" extract in Swann's Way is not devoid of playful mystification. The much-discussed similarities between Marcel and Proust already legitimise questions as to autobiographical veracity; but to complicate matters, Proust reportedly said that the steeples passage was an example of something he could have written as a child or young teenager (Ferré, 1960, p. 239). This is an odd judgement on a piece he actually wrote at thirty-six; are we to understand that his style evolved so little that he considered the piece perfectly plausible as an example of his young writing? Or that it evolved without his noticing, rendering him truly unable to tell the difference between a piece written by a precocious thirteen-year-old and one written by a thirty-six-year-old? Proust's early compositions are still with us, and it is easily verified that they do not have the sophistication of his mature work. An ungenerous reader could infer that this passage uses the character of young Marcel to exaggerate the quality of Proust's early work; Proust, one could say, is here "showing off" his precocious child self, protected by the fictional layers of In Search of Lost Time.

Looking more closely, though, the steeples passage is not actually passed off as young Marcel's work. Seemingly innocuously, the (adult) narrator introduces it to us as a "little fragment, which I have since discovered, and now reproduce, with only a slight revision here and there" (Proust, 1913/2005, p. 216). What kind of "slight revision"? We cannot know. It would of course be wrong to state that those changes correspond to the ones to which Proust himself subjected his original Figaro piece. Rather, this sentence suggests that there was, within the diegesis of Swann's Way, 
an anterior, un-adulterated piece; the "true" work of young Marcel, which the adult narrator Marcel subjected to a few changes before producing the text we are given.

Let us attempt to map that maze: the "steeples of Martinville" we know is a text Marcel Proust wrote at thirty-six, published in Le Figaro, then revised to adapt it to the fictional world he had created in Swann's Way, and inserted it there, where it became, within the diegesis, young Marcel's creation, itself with "slight revisions" by the old narrator Marcel. We would look in vain for any text written by young Marcel within the diegesis; that text, of course, is unavailable to anyone (see Landy, 2004). It is not even lost; it never existed. Yet, as the only intradiegetic example of the narrator's writing in the thousands of pages of In Search of Lost Time, followed up in the next volumes at crucial points of the narrative, the introduction of this "juvenile" piece is among the most striking moments of the overall movement of the novel.

Keeping Proust's steeples in shifting focus, I want to talk in this article about the adult effort to bury, frame, swaddle, but in so doing, also mark the presence and signify the importance of "childish scrawls." Children who write, whether in fiction or in reality, are never left in peace. Child-authored texts released into the public realm have typically been escorted by vast quantities of critical, paratextual and editorial adult additions. Like an army of prying aunts, with a mixture of loving admiration and disbelieving curiosity, adults read over the shoulders of child writers, commenting, analysing, comparing, marvelling about their works.

In their attempts to unearth child-authored texts, to study their reception or to smith tools for their literary analysis, researchers interested in such works necessarily wrestle with the abundance of adult discourse surrounding children's literary productions. Often, adults' words in the paratext, peritext and critical reception of child-authored texts are a pollution of sorts; they condition the reading of those texts as expressing an elusive "essence" of childhood, implicitly or explicitly denying them universal literary value, and simplifying the child writers' intentions, literary skills and critical positioning.

What I am interested in here, however, is precisely that shell of adult discourse around child-authored texts, and what it conveys of the adult's awareness of the presence of the child subject to the world. Adult words around the child's, I argue here, are oddly shaped. Troubled, deformed, so to speak, by the presence of the child's writing, they end up performing, themselves, by an intriguing process of contamination, the kind of childishness they wish the child-authored text could perform on its own.

Or, rather, the kind of childness they wish it could perform. This is where Peter Hollindale's concept comes into my analysis (1997). The childness of child-authored texts, I contend, emerges as a "composite," as Hollindale often says, of the actual child-authored text and its adult-authored escort. Juvenilia is "childly," and activates a reading event that focuses the attention of readers (young and old) on the matter and texture of childness, because it deforms the adult discourse around it. Without the suggestion of a child at the heart of the child-authored text, there would be no such potential for encounters with childness; but without the strangely-shaped adult discourse around it, that potential would equally be stifled.

To discuss that composite childness of child-authored texts, I look in this article at actual child-authored texts and their shell of adult discourse, as well as at the 
fictional child-authored text in Proust. As we shall see, the very suggestion of a child in the text-and a text in this child-whether actual or fictional, is enough to activate an adult discourse shot through with the possibility, and fantasy, of childness.

\section{The Suspicious Childness of Child-Authored Texts}

I begin by thinking of the ambiguous childness of child-authored texts considered on their own. The "steeples of Martinville" passage was not written by a child, but the extract does stand out, to some degree, in stylistic terms. In the first part of Swann's Way, full of slow walks, the passage jars, with its emphasis on speed and on the disturbing transformations of space as the onlooker accelerates and decelerates. The passage's ancestor in Le Figaro tells the exhilarating tale of a car journey, at a time when fast cars were something of a novelty. In Swann's Way, the automobile is replaced with a horse-drawn carriage; yet the unpredictable effects of speed remain similar. The passage is characterised by remarkable arhythmicality. Bell towers appear and disappear with stupefying speed, and then remain static for odd lengths of time. A "dilatory" steeple joins the other two "by a daring volt"; then, however, "The minutes passed, we were moving rapidly, and yet the three steeples were always a long way ahead of us, like three birds perched upon the plain, motionless" (Proust, 1913/2005, p. 216). Later on, as the narrator has almost given up hope of ever reaching his destination, the three bell towers suddenly arise before the carriage, "and they had flung themselves so abruptly in our path that we had barely time to stop before being dashed against the porch of the church" (p. 216). Jagged, exhilarating, exhausting, the passage stands out not just because of its unique status in the narrative as Marcel's work, but also because it does sound a little alien. The fact that it was not designed to fit into Swann's Way ensures, perhaps, a stronger feeling of extraneity than if the piece was written in the flow of the novel.

Does the alienating feeling of the steeples passage have anything to do with its status as fictional juvenilia? The "fact" of its writer's age within the diegesis is commonly picked up on by scholars; some have highlighted its flaws less ruthlessly, but no less sternly, than M. de Norpois (e.g. Keller, 1980, p. 1047). More recently, Hannah Freed-Thall (2009) analyses the passage as typical of, and surrounded by, key moments in In Search of Lost Time where the totalizing effort of the novel collapses, its "vertical" call towards theory and significance replaced by deictic glee. She calls "punctive" those moments in Proust which "do not signify, but rather 'prick', the beholder" (2009, p. 881). The passage, she says, "celebrates shifting surfaces and points, not penetrable depths, and foregrounds a logic of mutability, not monumentality" (p. 883). As such, it escapes the "cathedral" ambitions of the work, resisting the overall orientation towards signification (which Gilles Deleuze, in 1963, saw as the key to the novel). "Privileging not the arrival but the intermediary instant" (Freed-Thall, 2009, p. 878), not the naming but the showing, the text suddenly shows not the appropriation of the world through language, but its gloriously indigestible aspects, which can only be pointed out, as if with the index finger. Such moments have links, Freed-Thall says, to the Barthesian "c'est ça", the that's-good-for-me 
of jouissance (Barthes, 1973). They also have links, she says, to childishness. The banal object, apprehended by a childish mind, is pointed at, strikingly made present, not "recuperable to theory" (Freed-Thall, 2009, p. 873).

The steeples passage would thus be an example of what could be called (playing on Cixous) écriture enfantine, a writing splurge characteristic of the presence of the child in the world, expressed through a language which does not so much signify as point at; which does not so much appropriate and rearrange the world as present $i t$. These characteristics are understood (by adults) as aligned with the phenomenological experiences of childhood, or indeed other liminal conditions of being in the world, such as animality. Freed-Thall does not expand on her repeated references to "childishness", but one senses that she uses it not pejoratively, but to evoke a set of features common to the quality of being a child at a certain time in a certain context.

This notion is theorised by Hollindale, who calls it "childness" (1997). Childness is a floating and elusive label, referring to the expression through language of some features of the condition of childhood, connected to contemporaneous conceptions of childhood by adults and children themselves. The childness of a piece of writing is not dependent on its writer's age, since adult-authored texts can be childly (especially those which are particularly concerned with children's experiences, such as much of children's literature). In the case of child-authored texts, childness might be particularly expected; it is not unreasonable to think that the child-that being who occupies less space than "normal people" (namely, adults), who lives on borrowed territory, who stands in distinctive temporal disjunction with the people who organise most of their existence (see Beauvais, 2015), who is often addressed in an especially modulated language, who has a different range of clothes, cultural goods, furniture, tools and food and who, prominently, has had less experience of speaking, reading and writing - might produce a kind of language which both constructs and deconstructs that difference.

Freed-Thall's analysis of the steeples passage as intensely childish or, in Hollindale's coinage, childly, is compelling, though not entirely unproblematic. Firstly, the steeples passage does not truly escape the drive of the novel towards signification. For all its apparent hectic, deictic joy, it is quite easy to read the extract as allegorical—even impossible not to do so; the shifting steeples represent the delightful uncertainties of a future towards which the young writer is hurtling, only to see them fade into the distance as he draws away towards old age. There may be a presentational, punctive nature to the insert, but the steeples extract is also very much receptive to theory. Secondly, although the passage renders the sensations of the young narrator, Swann's Way is replete with similarly graceful attempts at capturing childly feelings; it is difficult to argue that the piece in itself is any "more childly" than other key moments in the novel, such as the famous drama of the bedtime kiss.

In other words, it is doubtful whether the extract in itself constitutes a groundbreaking example of childness. From the perspective of any educator with even minimal experience of children's writing, it is quite unconvincing as a young writer's piece; and if the piece is to be seen as formidably precocious, then this weakens its claim to childness. There is little space, in short, for arguing in favour of the authenticity of the passage as particularly childly as a consequence of its fictive child authorship. 
Yet there is something about those steeples playing hide-and-seek that is indeed perturbing. To a French ear, other meanings for "clocher" (steeple) arise: not just the noun, but also the colloquial verb "clocher," referring to the fuzzy, indeterminate feeling that something is awry, bizarre, not quite right. In the dance of the "clochers," there is "quelque chose qui cloche"; something troubling. What, exactly? I do not want to abandon Freed-Thall's idea that there is a "punctive", nontheoretical dimension in this extract-a childly dimension. Yet that dimension is to be sought, I argue, not inside but right outside —on either side —of the fictional child-authored text.

That either side is the discourse of the adult narrator, a discourse marked by hyper-awareness of a child's voice. It is that hyper-awareness that activates the childness of the text-by conferring childness on it. To further this analysis, I want to take a step back and consider the similarities between Proust's (fictional) childauthored text and some (real) child-authored texts of the same era.

\section{Child Writers and Their Adult Commentators}

By the late nineteenth century, the Western-particularly Anglophone-world was hungry for children's words. Like young Marcel's text, those "real" child-authored texts came securely contained within, and sometimes layered over by, adult words. A case study of the adult control over child-authored texts is the notorious publishing history of Scottish writer Marjory Fleming (see Langbauer, 2009). "Pet Marjorie" wrote every day in notebooks, from the age of six until she died at eight years old in 1811; following the rediscovery of her works fifty years later, there was almost another century of delay in the actual publication of said works. The resurfacing of Fleming's works began with a sentimental and highly fictionalised retelling of the young writer's story by H. B. Farnie in 1847, which quoted little of the original text. A Scottish doctor, John Brown, published another version of the Fleming story in 1863, again leaving little space for the girl's actual words. Later, writers Lachlan Macbean (1905) and Kate Wiley (1909) sprinkled yet more extracts amongst their own retellings. It took several decades for the complete works to percolate through to the general public; only in 1935 did a complete transcription of the child's diaries become widely available, a hundred and fifteen years after Fleming had written them (Fleming, 1935). The story of Marjory Fleming is exemplary of the ways in which a child-authored text can find itself, paradoxically, both unearthed and buried by sprawling, celebratory, invasive adult discourse, layering over, restraining and denying access to the original text of the child while seemingly making it available.

The importance for adults of children's words had begun earlier than the widespread publication of actual child-authored texts. It is difficult to overstate the role of the Romantic poets in presenting child figures as inspired interlocutors for adults, and the experiences of childhood as the origin of poetic creation. Children in the late eighteenth and early nineteenth century were seen as holding greater truths, though with insecure grasp. They occasionally dropped clues about their privileged knowledge, through outbursts of speech, often with the mystical impenetrability of a Pythia. 
These moments presented unique opportunities for the adults to educate themselves in the beyondness to which children had access. In Wordsworth's poetry, several child figures, pressed by adults to give answers, provide instead opaque statements which the adult listener marvels at, and (over)interprets. In "Anecdote for Fathers" (Wordsworth, 1798/2005), the child, asked if he prefers Liswyn Farm or Kilve by the sea, cannot provide an articulate reason for his preference for the former. He finally gives an erratic reply prompted by the view of a weather-cock on a house:

Then did the boy his tongue unlock,

And eased his mind with this reply:

At Kilve there was no weather-cock;

And that's the reason why.

O dearest, dearest boy! my heart

For better lore would seldom yearn,

Could I but teach the hundredth part

Of what from thee I learn.

"Unlocked tongue", "eased mind": the presentation of child speech as barely controlled, as relief from tension, would be taken as guarantee of the childly nature of poetic creation throughout the nineteenth and into the early twentieth centuries. For the Romantics proper, children were not yet thought of as writers; child voices and their teachings became ensconced in writing thanks to the poet. But by the end of the nineteenth century, the notion that children were privileged holders of greater truth had firmly become part of the cultural and literary discourse surrounding childhood, and triggered unprecedented interest in the internal lives and cognitive faculties of children (see Halverson, 1999; Redcay, 2012).

This interest whetted the appetite of Victorian and Edwardian readers for direct access to children's words, and justified the publication of a wide corpus of childauthored texts. In the 1920s, a wave of child writing overtook the Anglophone world, with several texts becoming best-sellers. Its onset is generally identified as the publication of nine-year-old Daisy Ashford's novel, The Young Visiters (1919), prefaced by J. M. Barrie. Yet, access to children's words was rarely provided directly. From the onset, adult criticism, editorial selection and discursive cushioning in the paratext conditioned, with varying degrees of absoluteness, the reading of those texts. "Children's texts are seen as incapable of standing alone, and like slave narratives are usually introduced by some document," says Cathryn Halverson (1999, p. 243). Primarily, those texts were seen as entry points into the inner lives of children, condensing an elusive essence of childhood characterised by ingenuity, freshness, spontaneity and purity. Their writing was thus treated similarly to the words of the semi-fictional children in Romantic poetry: a kind of miraculous outburst to be analysed and interpreted by adults eager to be taught.

To be taught, in particular, as to the matters of "childhood"; for those children were given representative power over their age category. Says Nunally Johnson of Nathalia Crane, in an introduction to the young girl's poems:

It happens that she is an extraordinarily articulate little girl, and if in some cases the conceits and fancies which she crystallizes are no rarer than those 
that, in all probability, throng the mysterious mind of every imaginative child, the explanation is simply that she is able to utter and clarify them, and these other children are, for the most part, normally unable to do that. (1924, p. Xviii).

And Lachlan Macbean of Marjory Fleming, in an introduction to Fleming's poems:

Marjorie interprets for us the consciousness of other children. As one writer well remarks, she is not so much a child genius as the genius of childhood, and "gets down on paper" the meaning of many a child's embrace. (1905, pp. v-vi)

This process recognisably fits within what Jacqueline Rose (1984) analysed as the central characteristic of the child-adult relationship, whereby the child primarily exists as a stabilising other of adulthood, a projector-screen for adult fantasies, crystallising adult desires and expectations. Because of the dominance of the "Rosean" model in contemporary thinking about the child, it is still difficult to recognise the child as subject, and to acknowledge the existence of childish forms of creation, control, appropriation or analysis of the world, to name just a few operations routinely refused by theory to the child (see Wallace, 2008; Gubar, 2011, 2013, 2016). In Rose's view, the adult obsession with childhood gives rise to tightly-controlled discursive islets—-such as children's books or, here, commentary on juvenilia-which superficially give the child a voice while keeping "the child" as a regulatory ideal, rather than a subject position.

In this perspective, the association between child-authored texts, children's literature, and children's literature authors, is logical. The connections between child writers and such children's authors as Barrie, Lewis Carroll or Rudyard Kipling locate the child poet "fad" as a companion discourse to and/or a by-product of Golden Age children's literature, dominated by the figure of the puer aeternus, of which Marjorie Fleming is a glorious embodiment. The adult discursive embrace around child-authored texts is a powerful validation of the Rosean argument: in theory and in practice, it would seem, there is much less text "in the child" than around it, produced and controlled by adult speakers.

As predicted by the Rosean argument too, scholars of juvenilia point out many ambiguities and internal contradictions in the adult discourse which surrounds and encloses the child's. Child writers were taken by adults to be both wildly original and entirely representative of their peers; both extremely adept at writing and no different from any normal child. The fragile equilibrium between those contradictory features was a condition of their success. Accusations of precocity were staunchly refuted, as the ideal child-authored text was not one that mimicked adult discourse or expertly superseded the ordinary language of children, but expressed the essence of childhood in a language unavailable to adults. This notably meant a different language, imperfectly handled, where spelling mistakes and incorrect grammar were relished as delicious oddities. Yet child writers were also sporadically criticised for their lack of technical skill, or for their over-reliance on metaphor; this was the most straightforward way to dismiss them as writers. In 1926, George Shelton Hubbell published a damning review of various young authors, calling Marjorie Fleming's work "bursts of pitifully inadequate song" (p. 318) and young Shelley a "juvenile 
blunderer" (p. 322). Both the celebratory and the critical discourses of adults thus contributed to the segregation of children's texts as a curiosity to be relished or discarded, rather than as legitimate literary texts whose authors could aspire to ownership, mastery and reflectiveness.

Just as with Proust's "steeples of Martinville" passage, the childness of childauthored texts itself is difficult to pinpoint outside of the adults' assertions that it is there. These assertions depend largely on material evidence vouching for the authenticity of the pieces as children's writing. Countless pieces of extratextual material were provided; frontispieces showed photographs or sketches of the children; in the case of Marjorie Fleming — who had been dead fifty years when her cult began - a proliferation of maps, genealogical trees, engravings, and facsimiles of her handwriting was provided. Within the books, authorship was vocally established: "The 'owner of the copyright' guarantees that 'The Young Visiters' is the unaided effort in fiction of an authoress of nine years," states J. M. Barrie in the first sentence of his preface (1919, p. vii). The obsession with age was a structuring force on the publications: Hilda Conkling's book Poems by a Little Girl (1920) is divided chronologically into subparts bearing the titles: "Four to Five years old," "Five to Six years old," etc.

The obsession with the childness of the child's text belies some adult uncertainty about the texts being convincingly childly on their own. Little Hilda Conkling, who dictated poems to her mother, was under particular scrutiny because of the absence of handwriting. Published in Poetry, her poems triggered suspicion from readers, who wrote into ask for "more explicit information as to just how those poems of Hilda Conkling's are done: To what extent does her mother select, rearrange and give form? Is it all actually improvised as given?" (Sapir, 1919, p. 344). Recurrently, editors, critics and the young poets' parents gave rigorous details about the process of transcription. "I do not change words in Hilda's poems, nor alter her word-order", her mother stated. "I write down the lines as rhythm dictates. She has made many poems which I have had to lose because I could not be certain of accurate transcription" (Driscoll and Sapir, 1919, p. 344). "No line, no cadence, is altered from Hilda's version; the titles have been added for convenience, but they are merely obvious handles derived from the text," says Amy Lowell in her preface to Hilda Conkling's Poems by a Little Girl (1920, p. x). Nathalia Crane, who attracted suspicion due to her unique situation as a child writer who was published without the editor's knowledge that she was a child, had to produce a poem under scrutiny by a journalist. At a time when no one could have been unaware of the work of editors on any adult writer's text, the lack of editorial interference in the children's texts was vocally asserted. "The pencilled MS. has been accurately reproduced, not a word added or cut out," says Barrie of Ashford's novel (1919, p. xix). The necessity to give evidence that a child had indeed written the text betrays the circular reasoning that the text's childness came from the author being a child, which in turn ensured the text's childness. Adults engaged passionately in asserting that childness; a very Rosean phenomenon.

In this context, the overbearing, overdiscursive adult, surrounding, enclosing and defining the child-authored text, can be perceived as an undesirable parasite. There has been continued effort by contemporary scholars of juvenilia to read such texts on their own terms, unlike other adult readers, who "accord the author's child status 
almost obsessive attention, to the extent, that her actual text is ignored or at the least made subordinate" (Halverson, 1999, p. 241). Anna Redcay, in a subtle doctoral study of child writing at the turn of the twentieth century (2012), used authors' ages as one of several criteria for analysing works especially concerned with childhood. She looked critically at such works not just in juxtaposition with one another, but also with adult-authored texts featuring child narrators, and other examples of children's literature. This is the approach I have taken, too, in this article: it allows Proust's encapsulation of young Marcel's fictional text and the sprawling adult discourse around Fleming's texts to be analysed alongside each other. Old Marcel's return to his own juvenilia also brings to mind similar operations by Opal Whitely or Daisy Ashford, whose juvenilia were rediscovered and published when they were young adults. In such readings, the literary value of the child-authored text, rather than its sociological or historical interest, is reclaimed.

Throughout such scholarly readings, though, it is evident that the proposition of a child-authored text being read in a literary way remains problematic. Its being located firmly outside of "general", "normal", adult-authored literary production, and the suspicions and desires that surround it, make it difficult to ignore its particular status. Several theoretical tools have been proposed to deal with this issue: among the most developed is Marah Gubar's defence of a "kinship model" (2013, 2016), which advocates resistance to the notion that the structuring concept of age in the adult-child relationship should be primarily divisive. In Gubar's view, it is towards similarity and resonances that we should turn our analytical radars, finding meeting-points rather than dichotomies between adulthood to childhood. This forcefully anti-Rosean view would allow for the consideration of children's voices and texts in their own terms, rather than as historical curiosities or in permanent comparison with adult works.

Calls for a kinship model approach to child-authored texts are convincing, but this perspective need not be the only one. The abundance of adult discourse around child-authored texts can be decoded in a way which provides insights into the childness of those texts-following, to a degree, Rose's theorisation-but which does not postulate a necessary lack of presence of the child subject. The forced childness of the child-authored text need not be binding, divisive and oppressive. As I will argue, it is fruitfully analysed as a quality of the adult text itself, marked by a heightened awareness of the presence of children in the world, and contaminated by that presence. I now move on to discussing the strangely childly texture of adult discourse surrounding child-authored texts.

\section{The Unbearable Childness of Adult Discourse}

The first, striking dimension of the adult texts surrounding child-authored texts is that, while they smother the child's text in their abundance, they also paradoxically display great impatience to show off said child's text. Adult Marcel cannot wait to present the child-authored text; he pretty much counts down to the time when the cherished insert will finally be there. In the two paragraphs which precede the "steeples of Martinville" insert, resonant assonances echo, not unlike the chiming of a 
bell—or, paying more attention to the thumping sounds of the words, the pulse of a heart: "clochers," "cocher," "causer," "caché," "chercher," "couché," "cahots." "Wait for it," the narrator seems to say in the run-up to the passage. Thus conditioned, the reader might tackle the text with a similarly accelerated pulse: something of importance, we understand, is going to happen. Those aspects of the text are clearly more "punctive" than totalizing (to go back to Freed-Thall's ideas); they scream "Look at this!" rather than "Let me explain."

This preemptive excitement is also present in adult-authored commentaries of (real) child-authored texts. Writing about Marjory Fleming, Brown incorporates the child's writing into his own critique, but this critique is only weakly explanatory: it relies mostly on anticipation. Often, short presentational sentences followed by a colon prepare the reader for the child's words. This litany of sentences reminds one of visiting a museum with an extrovert whose ecstatic energy makes up for their evident lack of artistic knowledge: "Here is a confession"; "This is delicious"; "This is beautiful"; "This is abrupt and strong"; "Here comes the world again"; "Here is her weakness and her strength again"; "Here is some more of her prattle"; "This is a higher flight"; "This last joke is good" (1864, pp. 20, 21, 24, 25, 30, 31, 32, 34).

Such sentences obviously condition the reader's engagement with the child's text: they point at what Brown considers to be the inherent childness of the diary. But they also point back - at the adult, animated with deictic restlessness. This deictic frenzy is animated with magical thinking, constantly pointing naïvely at fetish images and objects thought to make visible the children's talents. "'Effort,'... is an absurd word to use, as you may see by studying the triumphant countenance of the child herself," says Barrie of Ashford (1919, p. vii), taking as evidence the photograph of the child. "These lines and the meditation from which they spring were the spontaneous phrasing and the natural meditation of - a child of ten," marvels William Rose Benet in his foreword to Nathalia Crane's poetry (1924), the dash not unlike a finger pointed at an intriguing creature.

This adult presentation is often unnecessary and, just as often, stylistically quite inferior to the child's words. The steeples extract is preceded by the narrator's explanation of what triggers the writing fit; and this explanation tells the reader exactly what the insert will contain:

The steeples appeared so distant, and we ourselves seemed to come so little nearer them, that I was astonished when, a few minutes later, we drew up outside the church of Martinville.... Then it was time to start; I climbed up again to my place, turning my head to look back, once more, at my steeples, of which, a little later, I caught a farewell glimpse at a turn in the road. (Proust, $1913 / 2005$, p. 216)

These (unusually) brief sentences provide an efficient, but remarkably dry, synthesis of the steeples passage: the (adult) narrator parrots the "child's" text in advance of it. Kate Wiley's own story of Marjory Fleming (1909) is littered with such redundant pre-emptive paraphrase: "Marjorie confesses her sins, and desires punishment." Wiley announces, and proceeds to quote an extract from Marjory's diary which could not be clearer that it shows exactly that; ditto "she meditates upon serious subjects"; "In this first extract from her third journal Maidie expresses her 
gratitude to Isa Keith"; "she records her appreciation of the poets" (pp. 52, 54, 58). Those unnecessary presentations betray the adult's logorrheic need less to comment on, or interpret, than to repeat the child's work. The adult text, in other words, is contaminated to its core by the child's text.

Pleasure, the "that's-good-for-me" which Freed-Thall associates with a childly imagination, is also often more present in the adult commentary on child-authored texts than in the texts themselves. In Proust's text, the word "plaisir" appears four times in the two paragraphs preceding the steeples passage. Superficially, it is associated with the child rather than the adult. The child writes, says the adult narrator, "to appease [his] conscience and to satisfy [his] enthusiasm" (Proust, $1913 / 2005$, p. 216). The theme of spontaneity is omnipresent in adult discourse around child-authored texts. Remember the "unlocked tongue" and "eased mind" of the little boy in Wordsworth's "Anecdote for Fathers" and the assertions of spontaneity surrounding, in adult discourse, the works of child poets; the jouissance there accompanies the alleviation of some organic burden. Adult Marcel concludes, remembering his feelings as he finished writing:

at the moment when, on my corner of the box-seat, where the Doctor's coachman was in the habit of placing, in a hamper, the fowls which he had bought at Martinville market, I had finished writing it, I found such a sense of happiness, felt that it had so entirely relieved my mind of the obsession of the steeples, and of the mystery which they concealed, that, as though I myself were a hen and had just laid an egg, I began to sing at the top of my voice. (Proust, 1913/2005, p. 218)

The unexpectedly humorous (one could say, ridiculous) anticlimax to this crucial scene is reclaimed by Freed-Thall: "The desire to write is not unlike the urge to crow or squawk-not an appropriative act, but a responsive one, generated from the infantile or creaturely margins of speech" $(2009$, p. 886). These few lines also associate writing with, at best, organic reproduction, at worst, excretion-with the added suggestion of anal pleasure. The child's text is thus framed within a cloaca. However, this vertiginous drop to the basest kinds of jouissance, associated with the earlier stages of childhood, does not appear within the childauthored text itself; it is posited by the adult text around it. It is an effect of the adult fantasy of the text's childness.

The notion that the child's text is free-flowing is carefully maintained by adults. "The spelling unaltered, and there are no "commoes'," says John Brown, introducing Marjorie Fleming's works in 1864 (p. 18). There are no "commoes," indeed, in much of these children's poems and prose; the lack of punctuation, particularly striking in Daisy Ashford's novel and in Marjory Fleming's journals, feeds the impression of an unhindered, unmodified stream of consciousness. "It was important that the children be seen as spontaneously and effortlessly producing their work", notes Sadler (1992, p. 26); important, that is, because spontaneity and lack of clear intentionality were considered marks of childness. The children's poems themselves sometimes contributed to the notion that their work was effortless and inspired: 


\section{POEMS}

I know how poems come;

They have wings.

When you are not thinking of it

I suddenly say

"Mother, a poem!"

Somehow I hear it

Rustling.

(Hilda Conkling, 1922)

The ink was in the baby - he was bound to write a tale;

So he wrote the first of stories with his little fingernail.

(Nathalia Crane, 1924)

Adult commentators, as a result, are quick to assert the connection between the children's works and the work of the unconscious: "The poems are perfectly instinctive. There is no working over as with an adult poet. Hilda is subconscious, not self-conscious" (Lowell, 1920, p. xi).

Yet the writing "splurge" implied by the very idea of a child-authored text is rarely just on the child's side. Ironically, the quantity of adult discourse produced to introduce, conclude, comment on and ponder child-authored texts also gives a notable impression of effortlessness, inspiration and compulsiveness, sometimes far more so than the texts adults are commenting on. The adult drive to speak before and after the child reaches ludicrous extremes. After quoting just one line by Marjorie ("soft, silken primrose, fading timelessly"), Brown comments: "It is needless, it is impossible, to add anything to this"; and goes on to add a ten-line sentence with deliriously additive syntax: "the fervor, the sweetness, the flush of poetic ecstasy, the lovely and glowing eye, the perfect nature of that bright and warm intelligence, that darling child..." (etc.) (1864, p. 46). Far from giving the impression of a freeflowing childish text framed by austere interpretive work on the part of the adult, it is, more often than not, the adult who sounds like an unstructured graphomaniac. Exclamatory, enthused, trigger-happy with hyperbolic adjectives, commentators often appear more childishly excited than child poets themselves. Spontaneous overflows of powerful feelings are more likely found, in these texts, on the side of the adult than on that of the child.

\section{Conclusion}

Qu'est-ce qui cloche, then-what is awry? - in and around those child-authored texts? To an extent, it is the insistence on their childness, sometimes in the basest sense; the notion that writing at this stage of development is an irresistible, spontaneous, relieving movement, not unlike the loosening of the sphincter. Yet, alongside this pejorative treatment of child writing, the texts framing the extracts are often the ones truly animated with anticipatory glee, with deictic excitement: with childly characteristics. 
Adult discourses surrounding child-authored texts more often than not lend childness to those texts. The presence, or the suggestion, of a child-written text is powerful enough to perturb the language of the adult-authored text around it; the child's text might be approached by the reader with an "adulterated" perspective, triggered by the adult's text, but in return the adult's text is childified by its proximity to the child's text.

We might almost have forgotten that, in Proust's case, the text, it bears repeating, was not written by a child. Yet it functions as a text written by a child, less because of an intrinsic childness of the text than because the adult narrator's discourse around the insert activates a kind of reading event that favours a childly view. A childly text is doubtless there, even though there is no child-authored text. Its imagined weight is felt in the adult discourse; it displaces, disturbs and shapes the adult speech around it. Its existence is indubitable, as well as the hyper-awareness of a child subject behind it. The childness of the child-authored text is a fluid and elusive quality, but its importance can be observed, rather evidently, in the way in which the very suggestion of such texts deforms adult discourse. In this view, the Rosean explanation that adults are engaged in colonising, invading, controlling the child's discourse is only partly convincing. Adults do expect from the child-authored text a sense of childness, which it may or may not communicate as much as they'd wish. But by a strange transfusion, it is the adult language around the child's text which adopts and performs those childly characteristics.

Is there a text, then, in this child, or am I simply arguing, again, that there is no childhood outside of the category created by adults? From a "kinship model" approach, there is no denying that there are child authors, that there are childauthored texts, and that these texts are worth examining on their own terms. It is precisely the reason why there is space to theorise the childly text outside of a purely constructivist paradigm. I am arguing here for the nuancing of the Rosean model in the definition and theorisation of child-authored texts. The adult is not simply using the child and childhood as a regulatory instance for its desires, seeing in those texts only what it wants to see, and framing and enclosing it, the better to isolate childhood from adulthood. Instead, as I hope to have shown, adults are affected by the presence in the world of children's voices. They engage in reverent anticipation, circumscription, paraphrasing of the child's words.

While the childness of the child-authored text will remain a vanishing point-it is a fruitless endeavour to attempt to catch a "true" child's voice-its impact may be observed indirectly, just as celestial bodies invisible to telescopes may be detected by the characteristic way in which they deflect light around them. The adoption by adult voices of childly features, the suggestibility of adults to the surfeit of signification surrounding childhood, show that there is space to theorise the adult-child relationship in other ways than through, either, the promise of a pure entente cordiale, or straightforward dichotomy. The child's text is neither strengthened nor weakened by the embrace of the adult's text. It affects it, fundamentally, because the existence of children's words in the world affects adults. In that operation, finding winners or losers is a nonsensical endeavour; we might more fruitfully approach a text's childness, like Marcel's elusive steeples, at unpredictable speed, witnessing, in shifting focus, its "daring jolts." 
Open Access This article is distributed under the terms of the Creative Commons Attribution 4.0 International License (http://creativecommons.org/licenses/by/4.0/), which permits unrestricted use, distribution, and reproduction in any medium, provided you give appropriate credit to the original author(s) and the source, provide a link to the Creative Commons license, and indicate if changes were made.

\section{References}

Ashford, Daisy. (1919). The Young Visiters, or, Mr Salteena's Plan. Preface by JMB (pp. vii-xix). New York: George H. Doran.

Barthes, Roland. (1973). Le plaisir du texte. Paris: Seuil.

Beauvais, Clémentine. (2015). The Mighty Child: Time and Power in Children's Literature. Amsterdam: John Benjamins.

Brown, John. (1864). Pet Marjorie: A Story of Child-Life Fifty Years Ago. Boston: Ticknor and Fields.

Conkling, Hilda. (1920). Poems by a Little Girl. New York: Frederick A. Stokes.

Conkling, Hilda. (1922). Shoes of the Wind: A Book of Poems. New York: Frederick A. Stokes.

Crane, Nathalia. (1924). The Janitor's Boy, and Other Poems. New York: Thomas Selzer.

Deleuze, Gilles. (1963). Unité de "A la recherche du temps perdu". Revue de Métaphysique et de Morale, 68(4), 427-442.

Driscoll, Louise, and Sapir, E. (1919). Correspondence Concerning Hilda Conkling. Poetry: A Magazine of Verse, 14, 344-346.

Ferré, André. (1960). La vocation littéraire dans la vie et dans l'œuvre de Marcel Proust. Cahiers de l'Association internationale des études françaises, 12, 235-242.

Fleming, Marjorie. (1935). The Complete Marjory Fleming: Her Journals, Letters \& Verses. London: Sidgwick \& Jackson.

Freed-Thall, Hannah. (2009). Zut, zut, zut, zut: Aesthetic Disorientation in Proust. MLN, 124(4), 868-900.

Gubar, Marah. (2011). On Not Defining Children's Literature. PMLA, 126(1), 209-216.

Gubar, Marah. (2013). Risky Business: Talking about Children in Children's Literature Criticism. Children's Literature Association Quarterly, 38(4), 450-457.

Gubar, Marah. (2016). The Hermeneutics of Recuperation: What a Kinship-Model Approach to Children's Agency Could Do for Children's Literature and Childhood Studies. Jeunesse: Young People, Texts, Cultures, 8(1), 291-310.

Halverson, Cathryn. (1999). Reading Little Girls' Texts in the 1920s: Searching for the "Spirit of Childhood". Children's Literature in Education, 30(4), 235-248.

Hollindale, Peter. (1997). Signs of Childness in Children's Literature. Stroud: Thimble Press.

Keller, Luzius. (1980). L'autocitation chez Proust. MLN, 95(4), 1033-1048.

Landy, Joshua. (2004). Proust, His Narrator, and the Importance of the Distinction. Poetics Today, 25(1), 91-135.

Langbauer, Laurie. (2009). Marjory Fleming and Child Authors: The Total Depravity of Inanimate Things. Romanticism and Victorianism on the Net, 56 (n.p).

Macbean, Lachlan. (1905). The Story of Pet Marjorie (Marjory Fleming) With Her Journals, Now First Published. London: Simpkin, Marshall, Hamilton, Kent \& Co.

Mousson, Yvette. (1995). Sur deux pages de Proust: Les clochers de Caen. Cahier des Annales de Normandie, 26, 453-459.

Pholien, Georges. (1964). Les clochers de Martinville ou les débuts d'une vocation. Revue belge de philologie et d'histoire, 42(3), 907-912.

Proust, Marcel. (1913/2005). Swann's Way. Trans. Scott Moncrieff, Terence Kilmartin, revised D.J. Enright. London: Vintage.

Proust, Marcel. (1919/2005). Within a Budding Grove. Trans. Scott Moncrieff, Terence Kilmartin, revised D.J. Enright. London: Vintage.

Redcay, Anna. (2012). "The Long-Defended Gate”: Juvenilia, the Real Child, and the Aesthetics of Innocence, 1858-1939. Thesis submitted to the University of Pittsburgh.

Rose, Jacqueline. (1984). The Case of Peter Pan, Or the Impossibility of Children's Fiction. Philadelphia: University of Pennsylvania Press.

Sadler, David. (1992). Innocent Hearts: The Child Authors of the 1920s. Children's Literature Association Quarterly, 17(4), 24-30. 
Shelton Hubbell, George. (1926). Nathalia Crane and Some Other Child Poets. The Sewanee Review, 34(3), 318-328.

Wallace, Jo-Ann. (2008). Technologies of "The Child": Towards a Theory of the Child-Subject. Textual Practice, 9(2), 285-302.

Wiley, Kate. (1909). Pet Marjorie and Sir Walter Scott: The Story of Marjorie Fleming. New York: Cochrane.

Wordsworth, William. (1798/2005). “Anecdote for Fathers”. In Lyrical Ballads, with Samuel Taylor Coleridge. London: Routledge. 